\title{
GalNAc-Anti-C5 siRNA ALN-CC5
}

National Cancer Institute

\section{Source}

National Cancer Institute. GalNAC-Anti-C5 siRNA ALN-CC5. NCI Thesaurus. Code C120319.

A proprietary formulation composed of small-interfering RNAs (siRNAs) directed against terminal complement component 5 (C5) of the complement pathway conjug ated to a $\mathrm{N}$ acetylgalactosamine (GaINAc) lig and, which has potential use in the treatment of complement-mediated diseases, such as paroxysmal nocturnal hemog lobinuria (PNH). Upon subcutaneous administration of ALN-CC5, the GaINAc ligand moiety specifically binds to and is taken up by the asialoglycoprotein receptor (ASGPR) expressed on hepatocytes. Inside the cell, the siRNAs bind to C5 mRNAs, which results in the inhibition of both the translation and expression of the C5 protein. This lowers plasma C5 levels, prevents C5 cleavage into pro-inflammatory components and blocks complementmediated hemolysis. C5, a complement pathway protein, is expressed at high levels by the liver. 